\title{
THE POLITICAL ECONOMY OF HEALTH IN FRENCH TERRITORY AND THE GLOBALIZED PHARMACEUTICAL MANUFACTURING
}

https://doi.org/10.4215/rm2019.e18009

Antas Jr., R M a*

(a) Professor at Universidade de São Paulo, São Paulo - SP (Brasil)

ORCID: https://orcid.org/0000-0001-8393-0964.. LATTES: http://lattes.cnpq.br/7937525361167963.

Article history:

Received 14 February, 2019

Accepted 29 March, 2019

Published 15 May, 2019

\section{(*) CORRESPONDING AUTHOR}

Address: Departamento de Geografia - Avenida Prof. Lineu Prestes, 338. Cidade Universitária. CEP: 05508-000 - Caixa Postal:72042 - São Paulo.

E-mail: ricardomendes@usp.br

\section{ABSTRACT}

We approach the production of biomedicines in France as a productive spatial circuit. This circuit is part of the health-industrial complex (HIC), a concept that helps to explain the spatial and historical context to analyze the political economy of health care in France. Initially, we justify the use of the concept of the health-industrial complex, rather than the medical-industrial complex, as is commonly used in France and in Anglo-Saxon countries, and its relation to the political economy of health care. Then, we explain why the productive spatial circuit is more appropriate to a geographic approach of this industrial complex than the productive chain. Finally, we deal with the production of biomedicines and, more specifically, the importance of the Contract Development and Manufacturing Organization (CDMO) in the production of this technology to serve the major pharmaceutical laboratories, favoring the global production of this industrial branch.

Keywords: health industrial complex; productive spatial circuit; biomedicines; political economy of health care; France.

\section{RESUMO / RÉSUMÉ}

\section{ECONOMIA POLÍTICA DA SAÚDE NO TERRITÓRIO FRANCÊS E A PRODUÇ̃̃o FARMACÊUTICA GLOBALIZADA}

\begin{abstract}
Abordamos a produção de biomedicamentos no território francês como um circuito espacial produtivo. Esse circuito está entre outros que compõem o complexo industrial da saúde (CIS), conceito que permite entender o contexto espacial e histórico para a análise da economia política da saúde na França Inicialmente, justificamos o emprego do conceito de complexo industrial da saúde, e não complexo médico-industrial, como é comumente utilizado na França e em países anglo-saxões, e sua relação com a economia política da saúde. Depois, explicamos por que o circuito espacial produtivo é mais adequado a uma abordagem geográfica desse complexo industrial do que cadeia produtiva. Por fim, tratamos da produção de biomedicamentos e, mais especificamente, da importância que assume os Contract Development and Manufacturing Organization (CDMO) na produção dessa tecnologia para atender aos grandes laboratórios farmacêuticos, favorecendo a produção global desse ramo industrial.
\end{abstract}

Palavras-chave: complexo industrial da saúde; circuito espacial produtivo; biomedicamentos; economia política da saúde; França.

ECONOMIE POLITIQUE DE LA SANTÉ DANS LE TERRITOIRE FRANÇAIS ET LA PRODUCTION PHARMACEUTIQUE MONDIALISÉE

Nous envisageons la production de biomédicaments dans le territoire français comme un circuit spatial productif. Celui-ci compte parmi les autres circuits qui composent le complexe industriel de la santé (CIS), concept qui nous permet de comprendre le contexte spatial et historique afin d'analyser l'économie politique de la santé en France. Tout d'abord, nous justifions l'emploi du concept de complexe industriel de la santé, et non celui de complexe médico-industriel, couramment utilisé en France et dans les pays anglo-saxons, ainsi que sa relation avec l'économie politique de la santé. Ensuite, nous expliquons pourquoi le circuit spatial productif est davantage approprié à une approche géographique de ce complexe industriel plutôt que la chaine de production. Enfin, nous évoquerons la production de biomédicaments et, plus particulièrement, l'importance de la Contract Development and Manufacturing Organization (CDMO) dans la production de cette technologie dans la perspective de répondre aux besoins des grands laboratoires pharmaceutiques, favorisant ainsi la production globale de cette branche de l'industrie.

Mots-clés: complexe industriel de la santé; circuit spatial productif; biomédicaments; économie politique de la santé; France. 


\section{INTRODUCTION}

The line of reasoning proposed in this article is that some countries have health-industrial complexes (HIC) consisting of productive spatial circuits. These are industrial specializations dedicated to the supply of products that treat human health issues and exist on local, regional, and global geographical scales, due to the global character of production that the sector has reached in recent decades.

According to Santos (1988), productive spatial circuits are global production systems. There is compelling evidence of this in the growing flows of productive inputs between industries around the world, going beyond the flows of finished products between countries (ANTAS Jr., 2019). In Brazil, the French multinational pharmaceutical laboratory Sanofi is a textbook case of the circuit of productive and nonproductive agents between countries. In 2016 it was the pharmaceutical company with the highest revenues in the Brazilian pharmaceutical market.

The expression 'productive input' is used here to refer to a product manufactured for use in further industrial production, which may or may not result in a final product. This fact is essential for understanding the modus operandi of global industrial production, i.e., productive spatial circuits. Thus, the export and import data selected for this research only include products that have undergone some form of industrial transformation and have added value. The data analyzed does not include raw materials from agriculture or mineral extraction intended for export or import.

The existence, consolidation, and expansion of the HIC depend directly on the actions of the State, even though they may not be part of state enterprises. However, productive spatial circuits have developed as the corporations' rationale for action on a global scale, and guide the smaller companies' production, according to their strategies in different markets. However, these realities are not independent and autonomous or conflicting. In the political economy of health care, there is a strong symbiosis between States and industrial-based corporations.

\section{HEALTH-INDUSTRIAL COMPLEXES AND THE POLITICAL ECONOMY OF HEALTH CARE}

The conceptual formulation of a complex industrial structure explicitly focused on the production of medical and hospital supplies has existed for decades in different countries. Until at least the late 1980s, control of this structure was always identified with the USA/Canada, Western Europe, and Japan, known as the "triad". While the electronics industry and pharmaceutical laboratories were present in a large number of countries, a robust medical-industrial complex and wellness industry was restricted to these territories (RELMAN 1980; BROMBERG 1984; STARR 1983 and 1985).

Although these countries remain the world leaders in this productive specialization, the current landscape has changed. In 2016, in the pharmaceutical laboratory sector, the ten largest pharmaceutical markets were USA/Canada with 49.3\%, Western Europe with $15.4 \%$ (represented only by Germany, France, Italy, the United Kingdom, and Spain) and Japan with $8.4 \%$. Since then, China $(7.7 \%)$ and Brazil (2.4\%) have emerged as major pharmaceutical markets; in 2006 these countries were not among the top ten: 


\begin{tabular}{|l|c|c|}
\hline & $\begin{array}{c}\text { \% of the world } \\
\text { market in 2016 }\end{array}$ & $\begin{array}{c}\text { \% of the world } \\
\text { market in 2006 }\end{array}$ \\
\hline United States & 47.3 & 45.4 \\
\hline Japan & 8.4 & 9.4 \\
\hline China & 7.7 & n/a \\
\hline Germany & 4.5 & 5.3 \\
\hline France & 3.4 & 5.6 \\
\hline Italy & 3.0 & 3.4 \\
\hline Brazil & 2.4 & n/a \\
\hline United Kingdom & 2.3 & 3.4 \\
\hline Spain & 2.2 & 2.7 \\
\hline Canada & 2.0 & 2.6 \\
\hline Total participation in the world & $\mathbf{8 3 . 2}$ & $\mathbf{7 7 . 8}$ \\
\hline market & & \\
\hline
\end{tabular}

Table 1 - The major pharmaceutical markets in the world in 2016.

Source: QuintilesIMS 2016.

The significant change that has taken place in the medical-industrial complex as a whole is chiefly due to the sensu stricto production of the globalization process, which has brought new importance and strength to those places prepared to welcome industries in the sector and/or are strategically located to reach new markets (SCOTT and STORPER 1987, 220-222). The production of the specialized medical and hospital supplies industry has spread around the world from the 1990s.

Undoubtedly, the dissemination of productive units has not occurred homogeneously in countries, since there are territories outside the nuclei cited above that have a high or low incidence of industrial plants built before the globalization period, which is a vital factor when companies decide to expand their range. The health-industrial complex sector has expanded throughout the world, but some countries have experienced the process more intensely.

Brazil is an excellent example of this. In the 1970s and 1980s, research had already identified the existence of a medical-industrial complex in the territory (CORDEIRO 1980), but without parallels with the "triad." However, in the 1990s, when the globalization process grew beyond the financial and commercial sectors and reached industrial production, the picture changed significantly (SANTOS 1988; ANTAS Jr. 2017a). This was particularly true for the health industry, as its production activities in the national territory intensified considerably.

Due to this profound change in the industrial parameters of the medical-hospital suppliers in Brazil, Gadelha (2003) developed the concept of HIC, which is the productive and organizational arrangement of a better developed and disciplined sector that has closer institutional ties with the State. A new period began in the sector, a territorial division of labor emerged, which had a greater technological complexity and was more spatially fragmented than before. This did not only occur in Brazil, where there was a partial awareness of the intensification. The trend was especially strong in the main producing countries.

Strangely there are few references to the concept of HIC in French or Anglo-Saxon academic production, although they can be found. Usually, this productive structure is still called the Medical-Industrial Complex or Complexe Médico-Industriel, though some more recent studies have started to work with a revised conception (Balon et al. 2018). Initially, works on the subject often criticized the influence of capitalist enterprises on the medical corporation and the excessive medicalization in their approach to combatting disease. (DUPUY and KARSENTY 1974; SALOMON 1998). 
These designations are noteworthy and not just a matter of semantics. Although the two explanations justify their definition based on the formulation of the concept of a military-industrial complex (RELMAN 1980; Starr 1983; MENDONÇA and CAMARGO Jr. 2012;, GADELHA 2006; VIANNA, 2002, among others). The use of the word "health" rather than "medical" to define the industrial complex indicates that the formation of this economic sector is no longer restricted to the relationship of the large pharmaceutical laboratories and/or the electronic devices industry with the medical corporation. Instead, it is a set of public health policies, that is, it refers to a political economy of health in which the State is a crucial element:

[...] the health-industrial complex can be defined as an economic complex ... from a selected set of productive activities that maintain inter-sectorial relationships of buying and selling goods and services [...] and/or knowledge and technologies (ERBER 1992). Also, following a tradition of political economy that considers the market itself an institutionally constructed space, this particular set of economic sectors is inserted in a very particular political and institutional context given the specificities of the health care field. As a result of the convergence of sectors of activities, companies, public, and private institutions, and civil society in a particular economic space that generates investment, consumption, innovation, income and employment, it is an industrial complex (in the sense of activities that follow the industrial standard even though they formally belong to the service sector) as a concrete and empirical basis to delimitate a given analytical and normative locus (GADELHA 2003, 523/524).

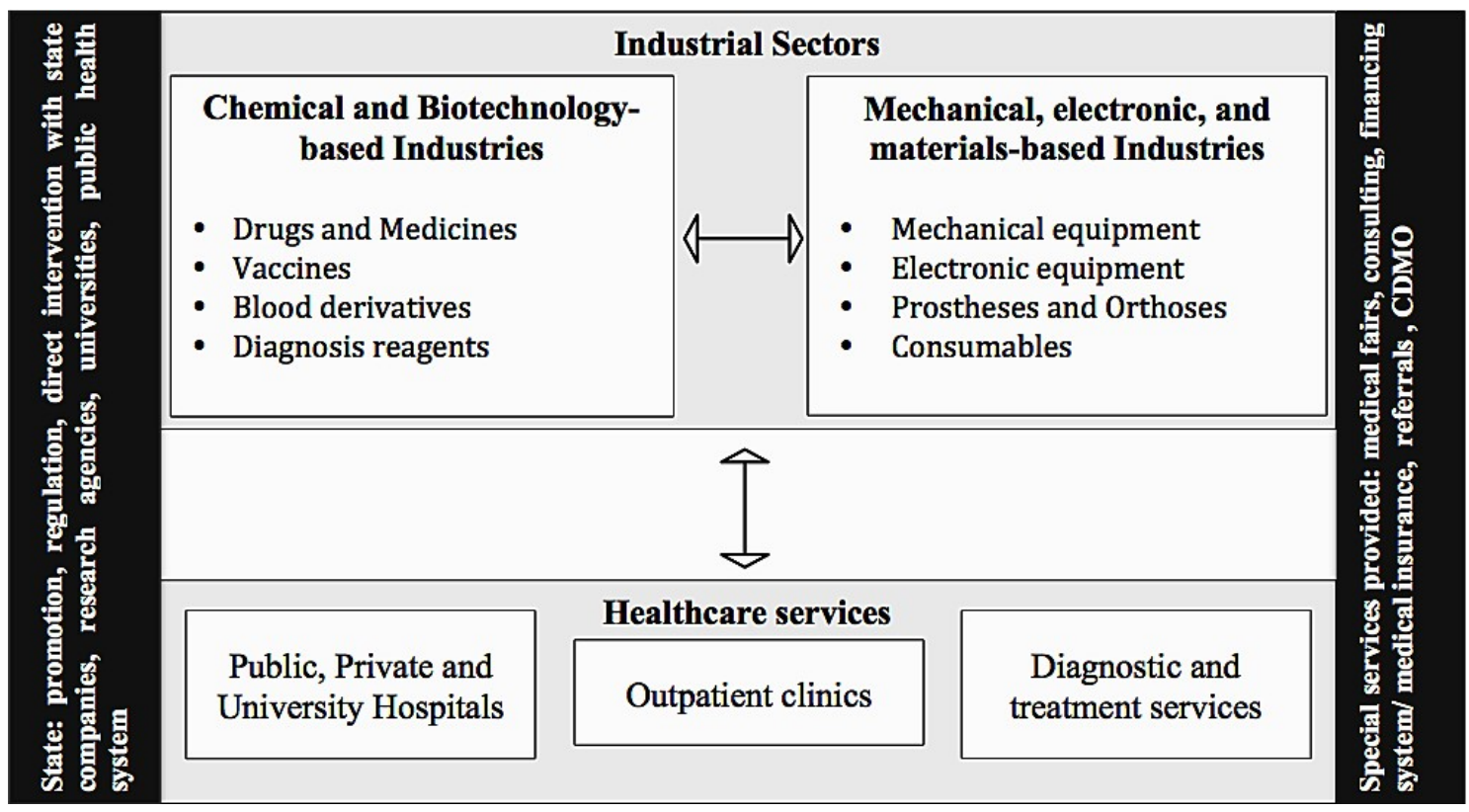

Chart 1 - A general schema of the health-industrial complex (HIC)

Source: Based on GADELHA 2003/2006 - extracted from ANTAS Jr., 2018.

Chart 1 is devised from two articles that Gadelha produced in 2003 and 2006 to show the main characteristics of a HIC. This explanatory diagram introduces elements such as the lateral rectangles (dark gray), which detail how the State and private services are responsible for the construction of global capitalist cooperation, and other less significant changes, which are addressed more thoroughly in another article (ANTAS Jr., 2018).

The interventions in Chart 1 were made because the analysis of the productive spatial circuits of this complex found gaps in the understanding of how HICs exist in a given national territory. Moreover, the global dimensions of this type of industrial production mean that the territorial division of labor includes productive apparatuses in different countries.

Gadelha's $(2003,2006)$ original proposal of industrial production presupposed a strictly economic 
approach and conceived of manufacture through productive chains and clusters. However, for a spatial, geography-specific approach it is fundamental to observe both the historical process that created this complex as well as the set of agents that coexist to accomplish this specialized production. Despite its enormous importance and current volume, the analysis of the process does not always take into account the health care sector's unique attributes and the specific demands that it imposes on production technologies in this field.

Hence, it is vital to consider the political economy of health care (VIANA et al. 2007), and its fundamental data, which include the circularity of the production, movement, and consumption of products to meet the demands of treating human health. Thus, we must consider industrial locations, the centralization of production in specific areas of the territory, the diversity of enterprises related to productive specialization, the concentration of capital, and the particular locations operating in the country and around the world.

The HIC needs to be understood according to the productive spatial circuits. It is the instrumental concept used to guide our analysis of the territory and the socio-spatial formation of which it is part. The concept implies that the broadest context is the global action of the most powerful economic agents. The global, nature of these circuits allows the recognition of command centers outside the national territories of specific productive specializations. The managerial strength is both in the concentration of capital operated by specific global companies and in technical-scientific innovations, developed in one country or another with patents granted to institutes and universities.

The crucial role of the State is evident in this last aspect. Regardless of how much companies invest in science and technology, governments always help foster innovation, in addition to the State's other roles in building a health-industrial complex.

Most of these considerations are based on the analyses carried out by economists, geographers, historians and others who specialize in public health and study the creation and performance of production-based companies in the health care sector (GADELHA 2006; VIANA et al. 2007) in the Brazilian territory.

Nevertheless, when we analyze health economics in the French territory, all the relationships that define a HIC are apparent. The forms of production, consumption, and promotion of products, as well as the creation of biotechnology parks and the implementation of industrial plants, demonstrate that competition between companies, which invest in innovation and the expansion of productive activity, is not based on "pure" market logic and free competition.

Instead, we find that the State organizes the role of each productive agent. Depending on products that correspond to the guarantee of sovereignty in the field of health care, the State intervenes to guarantee the autonomy of the French health system. The State prevents certain industrial products from becoming limited and holding the health system hostage to price escalations due to the forces of supply and demand, and so affecting the health care of the population.

An example of this is the creation of the Entreprise Français du Sang (EFS 2016) and the company, Laboratoire Français du Fractionnement et des Biotechnologies (LFB), both controlled by the State (100\% and 51\%, respectively). While the former guarantees the supply of blood products for hospital use and provides productive inputs to industries, LFB uses EFS plasma for fractionation and biomedical production.

The EFS is linked to public and private hospitals and outpatient services, with 150,000 laboratory units in French territory. It is responsible for blood collection, which must be legally obtained by donation, and has priority in this access. In 2016, three million donations went to the EFS's six industrial plants in France that produce plasma and other more complex derivatives, generating revenues of US\$ 995 million.

Part of EFS's production delivers industrial inputs for the manufacture of biomedicines. The principal customer is LFB; in 2016, 866,297 liters of plasma were supplied for this type of industrial production. Part of this input is used to make medicines ready for consumption. Another significant portion is inputs for large companies such as Sanofi, Novartis, as well as small and medium producers.

LFB's main products are related to immunology, hemostasis, rare diseases, and perinatal intensive care, as well as specialized services with the transfer of know-how. In 2016, their revenue was US\$ 575 
million, $30 \%$ of which came from exports or production in branches overseas 2 . The company operates in ten countries, including France, and has 20 production units, five of which are in French territory.

Another paradigmatic example that corroborates the existence of a HIC in France is the State's role in the consumption of all types of medicines. ${ }^{3}$ According to Les Entreprises du medicament (LEEM 2018), in 2016, the total turnover of the French drug market was US\$ 62.6 billion(Leem. It should be noted that this amount includes the export of medicines, which is currently at $47.7 \%$ and rising each year. However, the most important are the classes of medications for internal consumption of the remaining $52.3 \%$. Of these, $33.7 \%$ are reimbursable medications, $14.8 \%$ are consumed directly by hospitals (also mainly reimbursable), and only 3.8\% are non-refundable (FRANCE 2017). We shall return to this point later.

Without entering into the debate on the positive and/or negative consequences of this form of access to medicine, it is important to emphasize that in many situations, most, if not all, of the reimbursement comes from the State; which is the guarantor for the consumption of medicines in French territory. This margin of security for citizens allows the maintenance and expansion of the companies in the country.

The set of actions involving the State, industrial producers, hospitals, and outpatient clinics evidences the dynamic involvement of all the agents. Thus, the concept of productive chains is not sufficient to understand an economy as complex as health care, if the objective is to understand the role of the national territory in the political economy of health care. This should consider health care as a right, an economic good, and a field of capital accumulation (VIANA et al. 2007; ANTAS Jr. 2017a). Based on these three elements, health care can be divided into its social protection, political, and industrial dimensions (FREEMAN and MORAN 2002).

The territorial integration between the production of knowledge, the pharmaceutical market, the incentive to produce, the implementation of productive units, and the relationship between public and private agents is what provides the spatial dimension of this political economy of health care. Hence, the HIC is the best operational concept to analyze the production of medical supplies, since it provides a global understanding of the agents involved and the inherent differences in territories, which condition or encourage industrial production, especially those with global reach.

Furthermore, if the objective is to emphasize the spatial relationships working for or against the creation of this industrial complex, as well as the management and expansion of a political economy of health care inseparable from the territory that produces it, an analytical instrument based on a theory founded on geographic space is needed. In this case, the concept of the productive spatial circuit is a relevant proposal to address these issues (SANTOS 1988, 1996).

In the period of globalization, it is imperative that the capital flows and industrial production of finished products and productive inputs are not ignored, as they connect different locations and regions around the world. Hence the vital importance of understanding that these health-industrial complexes are composed of productive spatial circuits, and not only supply chains ruled by pure market logic.

\section{THE HEALTH-INDUSTRIAL COMPLEX AND PRODUCTIVE SPATIAL CIRCUITS: DISTINCT RELATIONSHIPS WITH SOCIO-SPATIAL FORMATIONS}

The concept of the production spatial circuit is an instrument used to analyze production processes on a global scale, as a counterpoint to regional economies (SANTOS 1988, 50; SANTOS and SILVEIRA 2001). This concept is central to the comprehension that global and regional scales of corporate industrial production are interdependent. Global flows depend on the locations and regions they cover to reach the necessary competitiveness and achieve their goals of expanding global added value.

Productive spatial circuits are technical and organizational systems of the productive sphere in their global dynamic. Analyses of the economic processes relating to agribusiness, the banking system, and industrial production (castilloCASTILLO and fredericoFREDERICO 2010; CONTEL 2011; 
ANTAS Jr. 2017a) recognize the emergence of combinations between wide-ranging hegemonic technical systems and the action systems that appropriate them. The selection and appropriation of the possibilities on offer are always a given in politics and therefore, a central element of the productive spatial circuit.

The processes engendered by transnational industrial corporations and their new ways of creating capitalist cooperation are corporate policies. The construction of a global arrangement among productive agents requires a policy of its own, with mechanisms that transcend the scale of socio-spatial formation. However, this takes place along with the States' traditional policies, which depend on the whole typology of industries. Indubitably, what we call "corporate policy" (SANTOS 1997) is restricted to corporate agents with a global presence, in many, but not all, national territories.

The construction of global capitalist cooperation is carried out by groups of agents interested in stimulating productive relationships because this is how they gain their share of global wealth production. They include employers' organizations, global trade fair companies specializing in productive sectors, financial and technical consultancies, and corporate legal production companies (Dezalay 1992)5, among other non-producing economic agents involved in global capitalist cooperation. Santos (1988) defined these specialized economic sectors in this global capitalist construction as spatial cooperation circuits.

Thus, such circles of cooperation characterize the production mode of company policies that imply the circulation of increasing volumes of money to achieve capitalist cooperation on a worldwide scale. Despite the expense, this has enormous benefits for the corporations' balance sheets, as well as distinguishing them from companies of other sizes, due to the decisions of global policies that participate in specific productive sectors and sometimes beyond them.

These productions always emerge in places that are present in the national economy and linked to regional policies to foster production, such as technology parks, tax incentives, the presence of skilled labor, and information and logistics networks (PERRAT 2006). Corporations expect the State to provide these items, even when they agree to help construct or strengthen these elements in the territory through advantageous exchanges. To describe the size of these deals and the exchanges of benefits in the territories requires a systematic analysis of productive specialization, which we seek to undertake in this analysis of pharmaceutical laboratories and biomedicines.

Before examining this productive specialization, it is essential to emphasize that, in addition to being a complex organization with productive spatial circuits for global processes, such circuits are not independent of State policies or their territorial sovereignty. Nor would it be correct to say that they depend on the "traditional State policies", since, in this historical period, sovereign power has very different contours from other eras and uses corporative organizational and technological systems to construct political power and the forms of intervention in their territory.

Among several forms of political action, it is noteworthy that States confer "relative legal autonomy" to corporate power and alliances have been made between them since at least the 1990s (FARIA 1999), in both developed and developing economies. Another fundamental aspect is the use of information and communication technologies in the political and economic organization of the territory (ANTAS Jr. 2017a).

A State influenced by corporate technologies is generally called neoliberal, which implies it is minimal or tends to the maximum diminution. This decrease is verifiable concerning the ownership of state-owned enterprises, but this does not necessarily indicate a decrease in their economic power, as evidenced by the constant growth of their appropriation of the wealth generated in economic activities as a whole.

In this process, there has been the economic/financial growth of many territorial States, primarily due to the growth of their capacity to raise revenue, a fruit of the same process that led to the reduction of social protection systems. Where once there was a constant effort to support the national economy with public money for the population and companies, now there are fiscal and financial control mechanisms and no impediment with subsidized investment. This neoliberal state is richer to serve corporate interests.

These agreements with transnational corporations reduce the States' responsibility to their population and increase corporate power vis-a-vis smaller-scale productive agents, which to a 
considerable extent used to depend on State actions in regional or local economies. Thus, with the reduction of the productive intervention of the State in the economy, national companies become more dependent on the policies of the big companies, which appropriate the added value generated by the productive agents restricted to the regional or local scale.

The emergence of global productive circuits is linked to the transformations of sovereign policies and the rise of global corporate power. An affirmation of the global dimension of industrial production must consider this comprehensive framework, involving the restructuring of the territorial division of labor on a world-wide scale. Such transformations can be better understood insofar as an analytical effort is made regarding an economic sector or specialization of this sector. The degree of technical-scientific and informational improvement attained requires this so that the effective corporate and state practices can be understood.

Theoretical generalizations about global processes regarding the international development of one economic sector or another often lead to logical explanations that are not always backed by real practices. There is, in fact, the homogenization of some practices necessitating some critical and necessary theoretical generalizations; on the other hand, each specific socio-spatial formation shapes such practices. The State's policies are an integral part of the productive spatial circuits, and the historical dynamics of each national territory present a distinct construction, with a political economy inseparable from its historical process.

For these reasons, we assume that the health-industrial complexes are national, while the productive spatial circuits that form them are governed by global corporate logics (SANTOS 1988; ANTAS Jr. 2015), although the circuits also include small and medium-sized enterprises with local, regional, or national coverage.

Thus, we assume that the HIC depends on a strong presence of the State in various ways for its existence, either through special credit lines, tax incentives, government purchases of medicines or even state-owned laboratories and industries, as well as institutional and regulatory arrangements. The State's encouragement of the cohesion of the health-industrial sector in the territory is crucial. On the other hand, for several decades there has been an increase in global corporate practices in finance, commerce, and, to a lesser extent, production (SCOTT 2006). Currently, the global production of large laboratories is a fact that reaffirms their power.

The productive spatial circuits of health care are composed of national industries of all sizes and technical-scientific capacity, which are controlled by corporations in terms of the global flows of productive inputs and finished products. These productive circuits can only be broadly understood by considering both the State and the health sector corporations.

Next, we analyze the presence of the productive spatial circuit of biomedicines that makes up the HIC in France, to identify what is unique to French territory and what is similar to other territories with similar productive structures. Therefore, this is not a comparative analysis, but instead, the intention is to comprehend how a division of labor has specific dimensions in a socio-spatial formation and how it maintains correlations with general processes that unite some or several national territories in the joint action of capital in this economic sector.

\section{THE PHARMACEUTICAL INDUSTRY AND THE PRODUCTIVE SPATIAL CIRCUIT OF BIOMEDICINES IN FRANCE: THE CONSTRUCTION OF CAPITALIST COOPERATION THROUGH CONTRACT DEVELOPMENT AND MANUFACTURING ORGANIZATION (CDMO) COMPANIES}

In the political economy of French health care, the Government is present on several fronts including the construction, maintenance, and regulation of all services linked to public health care, through the provision of public health facilities for all kinds of care, such as hospitals, urgent care, emergency services, as well as other health service institutions. Clearly, this involves the regular 
participation of the French State in the primarily public health care system.

The strong presence of the State is also felt in other circulation points of this political economy. The State has a diverse presence in the direct consumption of health products by citizens and the hospital system. It also participates in industrial manufacture by incentivizing production or even the creating strategic state-owned companies such as the EFS and LFB, mentioned above. In fact, in the consumption and manufacturing of health products in France, the separation between the public and private spheres is tenuous, and often wholly symbiotic.

One of the main features of this market is the influence of reimbursable medicines. Concerning consumption, families' spending on medicine using their private resources is generally subsidized as part of public health policy; the social security system reimburses most of these expenses. Thus, in 2016, from a total of approximately US\$ 25 billion of pharmaceutical laboratory sales, over US\$ 17 billion, or about $80 \%$, was reimbursed.

Under the general social security system, the different rates of reimbursement for medicines are $15 \%, 30 \%, 65 \%$, or $100 \%$ of the market price. Reimbursements of $65 \%$ and $100 \%$ were US $\$ 16.7$ billion out of a total of US\$ 17.3 billion. Overall, $71 \%$ of pharmaceutical revenue is from reimbursable medications.

These figures demonstrate how substantial the State's participation is in guaranteeing laboratory production. However, it cannot be assumed that this policy focuses exclusively on industrial production in the French territory; only $22 \%$ of the principal medicines reimbursed are produced in France. Furthermore, this performance is fragile because it is based on medications with lower added value. A striking feature of the French pharmaceutical market is that most of the production is of "mature medicines", that is, those that have been on the market for a long time, usually based on the main active ingredients and mostly generic drugs (France 2017, 21).

\begin{tabular}{|c|c|}
\hline $\begin{array}{c}\text { \% reimbursement of the price of the } \\
\text { medication }\end{array}$ & \% produced in France \\
\hline $15 \%$ & $49 \%$ \\
\hline $30 \%$ & $36 \%$ \\
\hline $65 \%$ & $23 \%$ \\
\hline $100 \%$ & $10 \%$ \\
\hline Generics & $30 \%$ \\
\hline
\end{tabular}

Table 2 - Share of French industrial production in the sale of reimbursable medicines in France - 2016

Source: LeemLEEM 2017a

Table 2 shows that a large share of the reimbursement of higher-value medications (in the $65 \%$ and $100 \%$ ranges) is for imported products. More serious, most sales of medications produced by French industries have a low added value, which has been the subject of criticism, from the government and employers' organizations. The latest-generation biomedicines, which invest heavily in scientific innovation, have a higher added value. Currently, these drugs have the highest consumption rates, and they are mostly imported. This theme will be discussed again below.

First, however, we will discuss some features of the participation of the pharmaceutical sector in the French HIC. Industrial pharmaceutical employment is a pillar of manufacturing production in the country. In 2014, it ranked second in the number of manufacturing jobs and eighth in the European Union, with 40,800 jobs (44,136 in 2016) and an estimated yearly impact of US\$ 5.5 billion.

In 2016, 271 industrial pharmaceutical plants were performing well, with technological expertise and extensive logistics capacity. Currently, this production apparatus is ranked fourth in Europe (behind Switzerland, Germany, and Italy), with an industrial production value of around US\$23.8 billion. From 1995 to 2008, France was first in this ranking (LeemLEEM and ROLAND BERGER 2018). 
In terms of total business, the pharmaceutical sector generated US\$ 61.8 billion, of which US\$ 29.1 billion was for export. This industry represents $5 \%$ of the value added for manufacturing production in France, and the mobilization of its productive capacity reached $80.2 \%$ in 2016, above the average for the industry as a whole in France, which is 79.9\% (LeemLEEM 2017a, 6/7/35, and 2017b, 66/79). France is the fifth largest force in the world drug market (Table 1), and the French Sanofi is the third largest company in the world market (QuintilesIMS 2017).

\begin{tabular}{|l|c|c|}
\hline & $\begin{array}{c}\text { The volume of business in } \\
\text { billion US\$ }\end{array}$ & \begin{tabular}{c} 
\% of the market \\
\hline 1. Novartis (Switzerland)
\end{tabular} $5^{-}$ \\
\hline 2. Pfizer (USA) & 50 & 5.5 \\
\hline 3. Sanofi (France) & 45 & 5.3 \\
\hline 4. Johnson \& Johnson (USA) & 41 & 4.8 \\
\hline 5. Gilead Sciences (USA) & 41 & 4.4 \\
\hline 6. Merck \& Co (USA) & 40 & 4.4 \\
\hline 7. Roche (Switzerland) & 39 & 4.2 \\
\hline 8. GlaxoSmithKline (UK) & 36 & 4.1 \\
\hline 9. Abbvie (USA) & 30 & 3.8 \\
\hline 10. AstraZeneca (UK) & 30 & 3.2 \\
\hline
\end{tabular}

Table 3 - The ten largest pharmaceutical companies in the world in 2016

Source: QuintilesIMS 2016.

Pharmaceutical production is among the main productive sectors that make up the HIC (Figure 1), maintaining high rates of investment in innovation despite the current unfavorable picture, which is less responsive to national and global demands. The French State plays a remarkable role in promoting cohesion globally in this industry for the companies that constitute the complex.

Sector data and analyses carried out by government institutions, employers' organizations, and research institutes supported by large pharmaceutical laboratories indicate an effort to make the country one of the largest producers of biotechnology, now considered the sector's "Achilles heel". This is because it is among the specialized areas of the pharmaceutical industry that generate higher added value and has the most significant deficit in the importation of medicines. One indicator of this poor performance is that, of 130 new molecules authorized by the European Medicines Agency (EMA) between 2012 and 2014, only eight were requested by laboratories in French territory (Roland Berger 2014).

\begin{tabular}{|l|r|r|r|r|r|}
\hline & Germany & \multicolumn{1}{|c|}{ UK } & France & Switzerland & Belgium \\
\hline Companies & 1.042 & 979 & 720 & 346 & 265 \\
\hline Workers & 37.000 & 30.000 & 11.000 & 20.000 & 15.000 \\
\hline Workers/company & 36 & 31 & 15 & 58 & 37 \\
\hline
\end{tabular}

Table 4 - Number of companies and workers in the main European countries in biotechnology in 2016.

Source: France Biotech 2017.

The production of biomedicines follows the logic of productive spatial circuits, with a very powerful dynamic in the global economy. According to the employers' organizations, France's underperformance is due to how the reimbursement policy works, as it contributes to low drug prices and a limited attractiveness to new companies. 
The industries on French territory continue to produce mature medicines that require less investment, which is related to the low prices (compared primarily to those paid in the United Kingdom, Germany, and Switzerland) and do not stimulate the entry of innovative biotechnology industries.

The productive spatial circuits are global, but they set up where they find strong markets for consumption and have the greatest territorial advantages to establish themselves. Again, the State is s a pillar of industrial development in the field of biomedicines in French territory, by generating and developing national companies willing to invest in this productive specialization or creating competitive advantages to attract industries (of all sizes) that dominate knowledge of biological medicines and the technologies for their industrial production.

Productive spatial circuits are constituted by the actions of both States and companies, mainly the pharmaceutical corporations. The action of both agents is observed in France, and there are strong associations between the corporate capital and the public authorities.

This is why actions are agreed between the State and capital; one example is the State's effort to create and stimulate the installation and expansion of "biotech parks". There are incentives for startups aimed at producing biomedicines, and inducements for consolidated companies, such as large laboratories, creating favorable conditions for agreements with universities and research institutes, such as the Pasteur Institute, which with Sanofi currently has one of the largest vaccine production plants in France and the world, in Lyon.

In 2005, the report La Place des biotechnologies en France et en Europe, produced by the National Assembly, demonstrated France's deficiency in the production of biotechnology and showed the growth in other countries with a tradition in the production of technologies linked to the "life sciences", particularly the United States, Germany, and Switzerland. The report pointed to the urgent need for the French State to promote such production, since "France is very bad in the field of pharmaceutical innovation" (FRANCE 2005, 44). At the time, between 2001 and 2003, of 53 products requesting a biotechnology-based production license in the world, only one was from France (FRANCE 2005, 45). Another more recent finding is that in 2017, the EMA authorized 91 new medicines, only six of which would be produced in France.

From 2007/2008 one of the State's first measures in the territory was the implementation of facilities and organizational structures with the launch of BioPolos, technological parks designed as "Network of poles of competitiveness in the area of health care" creating "agglomeration economies" (FRANCE 2014) to stimulate inter-company cooperation in the production of state-of-the-art technology (SCOTT 2006). Even though they are concentrated in particular regions of the country, the companies in each pole are present in others, to meet orders for productive inputs, logistical demands of circulation throughout the territory, or the realization of exports and imports, forming networks of poles.

The approach of the competitive pole is not only indicative of a change in the logic of public policies, it also concerns the different types of relationship that may exist between geographical proximity and the demands of innovation. (Perrat 2006 100)

The French State's efforts to promote pharmaceutical production through the implementation of Biopoles (Figure 1) are expressive: there are seven technological parks focused mainly on innovation, built after the French Congress debated the low investment in innovation (FRANCE, 2005). It is noteworthy that the State's participation is not limited to stimulating investment in the generation of added value, which is undoubtedly vital. There is also a commitment to guarantee a balance of industrial production in the political economy of health to avoid being held hostage to imports and thus ensuring the operation of hospital systems and supplying the biomedicines market. 


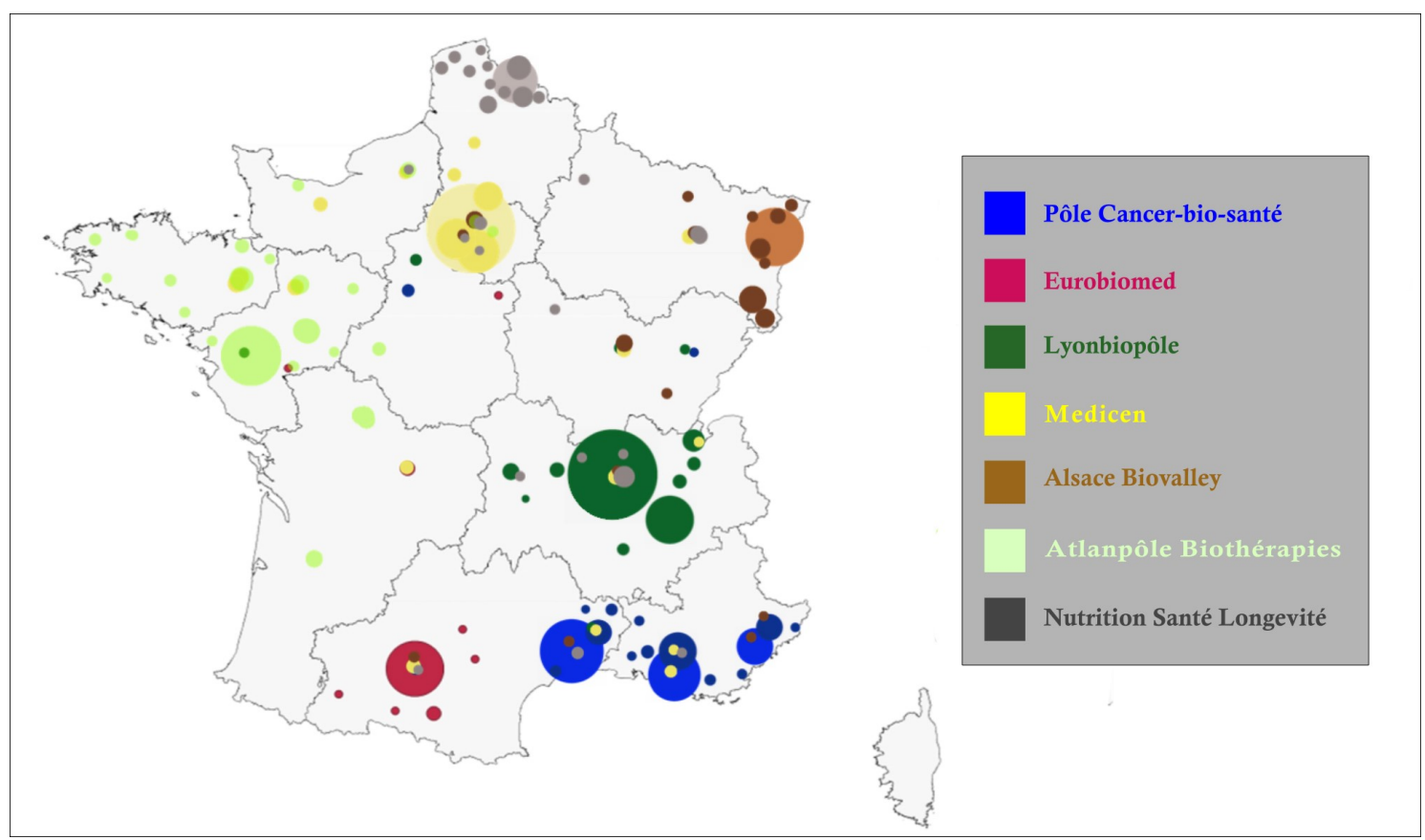

Figure 1 - Network of poles of competitiveness in the health area

Source: France (20072005, and website), LEEM (2014) - Org.: Author.

The pharmaceutical laboratories have established another movement related to the production of biomedicines. These are contracts in the form of Contract Development and Manufacturing Organizations (CDMO), known in France as production pour tiers, which have been gaining strength in the pharmaceutical market and are not exclusive to the production of biomedicines.

In the worldwide pharmaceutical market, this type of company is very attractive for this type of production, which involves the extensive application of knowledge. Companies specializing in CDMO contracts managed to promote their association with Big Pharma as well as with large and medium-sized laboratories.

The 40 years during which Pharmaceutical Technology has served the bio/pharmaceutical industry have been years of momentous growth and change in the way drugs are discovered, developed, manufactured, and sold. Contract development and manufacturing organizations (CDMOs) have long played a part in the industry's growth, but it is only in the past 20 years that they have become a critical element in bio/pharmaceutical company operations (MILLER, 2017, p. 77).

CDMOs are companies that serve others in the pharmaceutical industry by providing services ranging from drug development to drug manufacturing. This permits the leading companies to outsource certain aspects of their interests to assist in production to scale or allows the large company to focus on drug discovery and marketing (Ernst \& Young 2017, 3).

Services offered by the CDMOs include pre-formulation, formula development, stability studies, method development, preclinical and Phase I clinical testing materials, end-stage clinical trials, scaling up, batch registration and commercial production, and accreditation from government agencies in different countries. The CDMOs are contracted manufacturers, but sometimes start-up companies that invest in innovation projects are created, freeing the large laboratories from the risks inherent in the development of new drugs, choosing to buy or split the patent.

One of the reasons that CDMO companies grew moderately in the early 1990s was the reluctance of the large laboratories, as they feared compromising the brand's credibility in specific niche markets, directly interfering with sales. In a 2016 report, Sanofi justified the need to adopt this practice with reservations 6. 
It is not unusual for a CDMO company to acquire an industrial plant from a Big Pharma to supply it with products, guaranteeing exclusivity for a specific period. However, if a CDMO has idle productive capacity, it may contract with other market agents.

An essential characteristic of this class of company is their presence in several countries, acting as the base to supply products that meet the rigid standards required by large laboratories and their technological production. Fareva is found in 10 countries with 17 branches. Another company present in France is Delpharm, which bought 12 industrial plants from major pharmaceutical companies, most of them in France.

\begin{tabular}{|l|l|l|}
\multicolumn{1}{|c}{ Company } & \multicolumn{1}{c|}{ City } & \multicolumn{1}{c|}{ Year } \\
\hline Delmas perfusion & Tours & 1984 \\
\hline Syntex [Roche] & Brétigny & 2002 \\
\hline Pharmacia [Pfizer] & Evreux & 2006 \\
\hline Schering [Bayer] & Lille & 2008 \\
\hline Boehringer Ingelheim & Reims & 2011 \\
\hline Novartis & Huningue & 2012 \\
\hline Laboratoires Besins & Drongenbos & 2012 \\
\hline Bayer & Gaillard & 2013 \\
\hline Pfizer & Lyon & 2015 \\
\hline Sanofi & Dijon & 2016 \\
\hline Takeda & Novara & 2017 \\
\hline Roche & Milan & \\
\hline
\end{tabular}

Table 5 - The acquisition of industrial plants by Delpharm

Source: Delpharm Company Website. - Org. Author

The emergence of this type of company plays a key role in establishing global capitalist cooperation, facilitating the work of the large laboratories in concert with global productive actions.

Table 6Chart 2 shows the principal industrial brands operating with CDMO contracts in France. Those that specialize in CDMOs are listed, such as Carbogen, Novasep, and Recipharm, among the largest, and others operate in a mixed format; even Sanofi works as a CDMO in French territory. 


\begin{tabular}{|c|c|c|c|c|}
\hline COMPANY & $\begin{array}{c}\text { Relationship } \\
\text { with } \\
\text { Property }\end{array}$ & $\begin{array}{l}\text { Export } \\
\text { rate in } \\
2016(\%)\end{array}$ & Country (production) & Class of biomedicines \\
\hline ABL Europe & $\begin{array}{l}\text { Advanced } \\
\text { Bioscience } \\
\text { Laboratoires } \\
\text { INC. }\end{array}$ & 35.15 & France (1) & Viral vectors \\
\hline ACCINOV & Independent & 0 & France (1) & $\begin{array}{l}\text { Recombinant proteins, RNA, bacterial } \\
\text { microbiota extracts, viral vectors, protein } \\
\text { extraction, vaccines }\end{array}$ \\
\hline AmatsiDBI & $\begin{array}{l}\text { Amatsigroup } \\
\text { Eurofins }\end{array}$ & 19.47 & $\begin{array}{c}\text { France (2), USA (1), } \\
\text { Belgium (1) }\end{array}$ & $\begin{array}{l}\text { Recombinant proteins, Packaging for } \\
\text { biological biomedicines }\end{array}$ \\
\hline BIO ELPIDA & Independent & 87.05 & France (1) & $\begin{array}{l}\text { Recombinant proteins, vaccines, cell } \\
\text { therapies, microbiota bacterial extracts }\end{array}$ \\
\hline CARBOGEN AMCIS & $\begin{array}{l}\text { Grupo } \\
\text { Dishman } \\
\text { Carbogen } \\
\text { Amcis }\end{array}$ & 64.59 & $\begin{array}{l}\text { India (1), China (3), UK (1), } \\
\text { France (1), Switzerland (3), } \\
\text { Holland (2), Singapore (1) }\end{array}$ & RNA \\
\hline CELLforCure & LFB / France & 0 & France (1) & Cellular therapies, Genetic therapies \\
\hline Clean Cells & Independent & 36.09 & France (1) & Cellular therapies, Viral vectors \\
\hline $\begin{array}{l}\text { Delpharm } \\
\text { Huningue SAS }\end{array}$ & Delpharm & 11 & $\begin{array}{l}\text { France (9); Belgium (1); } \\
\text { Italy (2); }\end{array}$ & Recombinant proteins \\
\hline $\begin{array}{l}\text { EFS Atlantic Bio } \\
\text { GMP }\end{array}$ & $\begin{array}{l}\text { Etablissement } \\
\text { Français du } \\
\text { Sang-EFS }\end{array}$ & 0 & France (1) & Viral vectors \\
\hline FIRALIS & Independent & 13.05 & France (2) & Recombinant proteins \\
\hline GENBIOTECH & $\begin{array}{l}\text { Laboratoires } \\
\text { Genévrier SAS }\end{array}$ & 0 & France (1) & $\begin{array}{l}\text { Recombinant proteins, cell therapies, } \\
\text { genetic therapies, biological tissues, RNA }\end{array}$ \\
\hline Invivogen & Famille Tiraby & 0 & $\begin{array}{l}\text { France (1), USA (2), Brazil } \\
\text { (1), Hong Kong (2) }\end{array}$ & RNA \\
\hline NOVASEP & NVHLS.A. & 83.44 & $\begin{array}{l}\text { France (6); Belgium (2); } \\
\text { Germany (1); USA (1); India } \\
\text { (1); Thailand (1); China (1) }\end{array}$ & $\begin{array}{l}\text { Recombinant proteins, vaccines, protein } \\
\text { extraction }\end{array}$ \\
\hline PX'THERAPEUTICS & $\begin{array}{l}\text { Aguettant } \\
\text { Santé }\end{array}$ & 14.75 & France (1) & $\begin{array}{l}\text { Recombinant proteins, } \\
\text { vaccines, protein extraction, microbiota } \\
\text { bacterial extracts }\end{array}$ \\
\hline $\begin{array}{l}\text { Recipharm in } \\
\text { Monts }\end{array}$ & $\begin{array}{c}\text { Recipharm AB } \\
\text {-Publica } \\
\text { Limited } \\
\text { Liability Co. }\end{array}$ & 25.11 & $\begin{array}{c}\text { Sweden (11), Portugal (1), } \\
\text { France (4), UK (6), Span (1), } \\
\text { Brazil (1), Italy (1) }\end{array}$ & vaccines \\
\hline Sanofi Aramon & Sanofi & 27.84 & France (3) & protein extraction \\
\hline $\begin{array}{l}\text { Sanofi Genzyme - } \\
\text { Lyon Polyclonals }\end{array}$ & Sanofi & 62.49 & $\begin{array}{l}65 \text { countries (including } 17 \\
\text { industrial plants and } 9 \\
\text { laboratories) }\end{array}$ & Viral vectors \\
\hline Transgene SA & $\begin{array}{l}\text { Compagnie } \\
\text { Mérieux } \\
\text { Alliance }\end{array}$ & 0 & France (2); US (1); China (2) & Viral vectors \\
\hline Yposkesi & Genethon & 9.06 & France (1) & Genetic therapies \\
\hline
\end{tabular}

CHART 2- Biomedical industries in the frenchFrench territory with CDMO contracts in 2016

Source: Orbis Platform, 2018; LeemLEEM 2018. - Org. ANTAS Jr.

CDMO-only companies are located in many countries to serve the productive pharmaceutical structure by providing inputs or producing the completed medication (particularly generics). According to an Ernst \& Young report (2017, 2-16) "Consolidation of the CDMO industry: opportunities for current players and new entrants," the pharmaceutical CDMO industry is very fragmented. There are around 600 global and local companies and in the last decade has been an intensive process of mergers and acquisitions (in 2016, a total of US\$ 16.2 billion worldwide). 


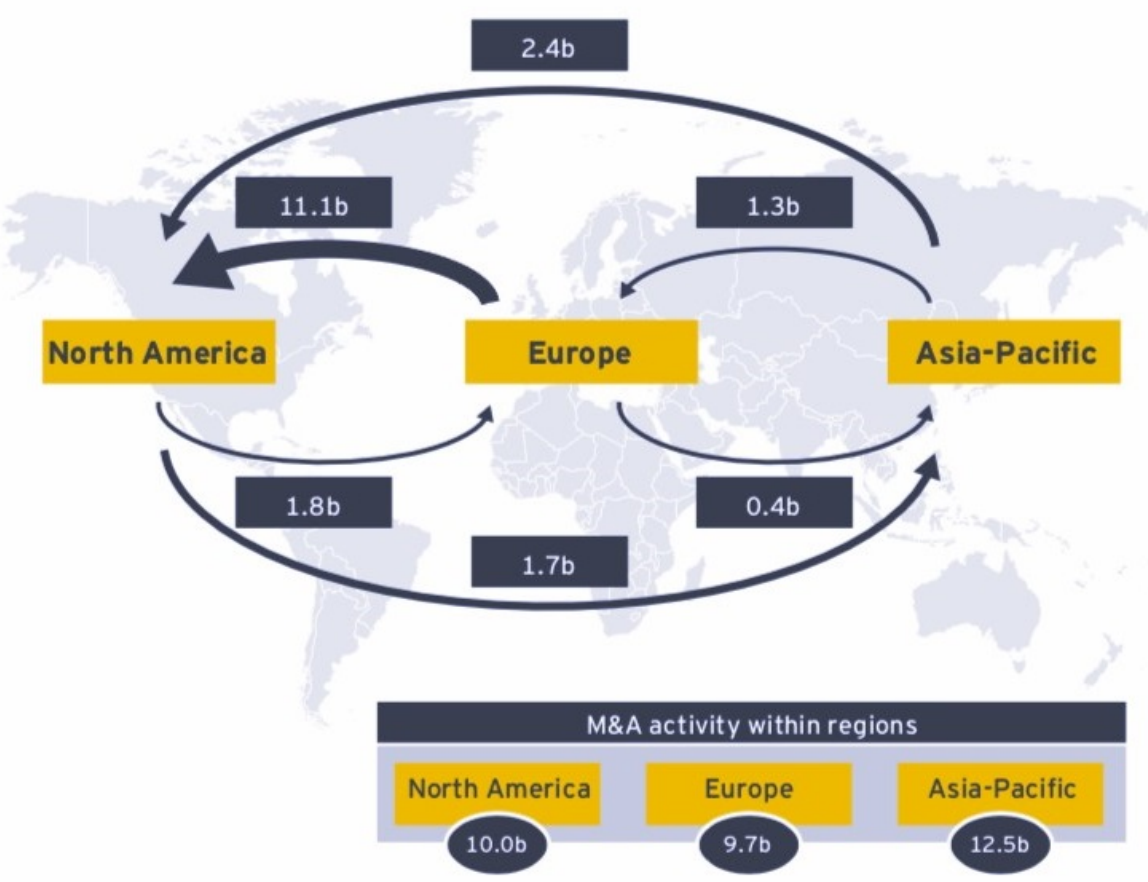

CDMO investment streams between 2012 and 2016. Arrows originate in the region of the acquirer, arrowheads point toward the region of the target. Values indicate implied EVs (in US\$b).

Figure 2 - Investment flows through Mergers \& Acquisitions

Source: Ernst \& Young. 2017

These companies carry out intense transfers of inputs between their units in different countries to serve the markets, obtaining competitive advantages (cheaper raw materials to produce inputs, associated with specialized work with lower remuneration). This results in more input flows for the large laboratories, from the territory where the CDMO is located and to others. Often, the most expressive global input flows are between the branches of a corporation. This logic of a territorial division increasingly based on the technical-scientific fragmentation of production is a fundamental characteristic of contemporary productive spatial circuits.

Using the largest pharmaceutical market (which trades with almost every country in the world) to illustrate this dynamic: for productive inputs alone (excluding raw materials) in 2003, the United States exported US\$ 4.3 billion and imported US\$ 3.5 billion; in 2010, they exported US\$ 12.1 billion and imported US\$ 9 billion; and in 2017, they exported US\$ 10.9 billion and imported US\$ 12.2 billion.

\begin{tabular}{|l|c|c|c|c|c|c|}
\hline \multicolumn{2}{c}{} & \multicolumn{2}{c}{$\mathbf{2 0 1 7}$} & \multicolumn{2}{c}{$\mathbf{2 0 1 0}$} & \multicolumn{2}{c|}{2003} \\
\cline { 2 - 8 } & US\$ & $\mathbf{\%}$ & US\$ & $\%$ & US\$ & $\%$ \\
\hline Exports of inputs & 10.9 & 24,0 & 12.1 & 29,7 & 4.2 & 26,4 \\
\hline Imports of inputs & 12.2 & 12,7 & 8.9 & 14,5 & 3.5 & 12,6 \\
\hline Exports of finished drugs & 34.5 & 76,0 & 28.7 & 70,3 & 11.7 & 73,6 \\
\hline Import of finished drugs & 83.8 & 87,3 & 52.6 & 85,5 & 24.3 & 87,4 \\
\hline
\end{tabular}

Table 6 - Movement of exports and imports of inputs for drug production and finished medications between the US and the world, in US\$ billion

Source: U.S. Import and Export Merchandise trade statistics. 
The practice of exchanging inputs has clearly supported the strong growth of exports and imports of finished medications (Table 76). Thus, the growth of input flows (not just packaged medications or packaged doses) is a characteristic of the territorial division of labor, at least as far as the pharmaceutical market is concerned.

The production of standardized and suitable inputs for other production lines, distributed in different countries, is the area of expertise of the large CDMO companies. The flow of productive inputs has established itself as the modus operandi of productive spatial circuits, by increasingly promoting the completion of the product in various parts of the world, often simultaneously.

We do not perceive this simultaneity as fortuitous; it is a gradual construction that takes advantage of a new manipulation of the space-time relationships that occur in each socio-spatial formation in favor of capitalist and corporate accumulation (ANTAS Jr., 2019).

\section{CONCLUSIONS}

The structuring relationship of the health-industrial complex with the State parallels the importance of corporations in the formation and control of productive spatial circuits. This concept of a productive complex gains structure where States have a strong presence in the health economy, through the provision of services, regulation, and direct intervention. In turn, corporations have become responsible for the formation of productive spatial circuits of global scope (SANTOS, 1988).

As Freeman and Moran (2002) point out, when health gains the dimension of a social structure with services created to provide care for human life, throughout its historical formation it also invokes production, commerce, and finances. Politics drives the relationships between these different economic sectors. Moreover, when the health service is public and universal, as in France, the market's obligatory relationship with the state requires agreements and cooperation over territorial planning, giving even more defined contours to the HIC.

The health-industrial complexes are formed where States are able to provide the territory with systems of hospitals and emergency care, the production of knowledge, inspection and more. They form a political economy of health that is specific to the economic and social development of the country since large urban populations require technical and organizational conditions for the treatment of human health.

We emphasize, however, that the global logic of corporations was not established simultaneously in the productive places and regions of different countries, nor all their economic activities, having first experienced finance and marketing (in the case of pharmaceutical and many other companies ). The sector's productive dynamics is installing itself intensely, but it has taken time to reach the current level. The use of simultaneity as a competitive factor (ANTAS Jr., 2019) to control particular productive specializations is restricted to the exchange of productive inputs and finished products between a group of about 50 countries that have the industrial apparatus to participate in the spatial circuits. However, just 20 of these countries account for $90 \%$ of these exchanges (US TRADE, 2018).

Thus, it is essential to remember that productive spatial circuits are global but not planetary. They are global through the transnational practices that corporations construct with the spatiality and the historicity of the production, unlike the other companies in the countries in which they are present. CDMO companies illustrate these practices to broaden global capitalist cooperation by responding to the productive and legal demands involved in drug manufacturing, particularly biomedicines.

Therefore, we verified the expansion of productive spatial circuits despite the 2008 global crisis. In reports from States and large corporations, we find the assertion that health does not keep pace with other sectors during economic crises. This is due to the political economy of health in which the State is present and to the socially attributed value to the care of human health.

The expansion continues due to the demand of the health services, which is also growing, especially in countries with large urban populations. It is in these countries that we are witnessing the intensification of corporate practices that seek to operate new forms of the space-time relationship to increase the competitiveness of industrial production. 


\section{NOTES}

1 The term productive input refers to a manufactured product whose purpose is to be used in further industrial production, for final products or not.

2 A large part of the company's business outside France is generated in Brazil, either by the construction of the Brazilian public company Hemobras, in which LFB participates and to which it sells technology and equipment, or by successive large sales of immunobiological products.

$3 \mathrm{We}$ limit ourselves here to only addressing medicines, but this affects other areas of the complex such as imaging diagnostics and implant prostheses.

4 Although it is not possible here to deepen the theoretical content of the socio-spatial formation category, note that there is a correspondence with the Marxist category of economic and social formation, considering both historical and geographic formation (SANTOS 1977, 05) "The modes of production write history in time; social formations write it in space. Taken individually, each geographic form is representative of a mode of production or of one of its moments. The history of modes of production is therefore, from this precise standpoint, the history of the succession of forms it has created in its service. The history of social formation is the history of the superimposition of forms created by the succession of modes of production, of their entanglement with its 'spatial territory'."

5 We refer here to the theoretical perspective of contemporary legal pluralism, particularly in the economic field, with private legal developments to resolve corporate litigation with the expedient arbitration, a lex mercatoria (FARIA, 1999); transnational legal mechanisms of organization, global standardization of production, new forms of accounting with private legal authorizations for non-taxation by state authorities, etc. (ANTAS Jr. 2017b).

6 The 2016 Activity Report initially found that "Sanofi chose to internally integrate the manufacturing of its products to better control its quality" and then "Some elements of production are outsourced [...]. Sanofi's main pharmaceutical subcontractors are Famar, MSD, Unither, Delpharm, and Saneca" (Sanofi 2016, 117).

\section{ACKNOWLEDGEMENTS}

This article is based on a project supported by the São Paulo Research Foundation (FAPESP), Process N. 2017/21787-0. "The opinions, hypotheses, and conclusions or recommendations expressed in this material are the responsibility of the author (s) and do not necessarily reflect the views of FAPESP". The Conselho Nacional de Pesquisa e Desenvolvimento (CNPq), process 307702 / 2017-0, also supported the production of this article.

\section{REFERENCES}

ANTAS Jr., R. M. A articulação dos aconteceres na construção dos fluxos globais: notas sobre o circuito espacial produtivo de medicamentos na França e no Brasil. 2019. Inédito.

ANTAS Jr., R. M., e THERY, H. O complexo industrial da saúde no território francês: uma análise do circuito espacial produtivo de biomedicamentos. 2018. Inédito.

ANTAS Jr., R. M. A economia política da saúde no território brasileiro e seu complexo industrial: uma análise a partir do conceito de circuito espacial produtivo. Sociedade \& Natureza, Uberlândia, 29 (2): 243-256, nov. 2017. ISSN 1982-4513. Disponível em: .

ANTAS Jr. Complexos industriais, circuitos espaciais produtivos e direito reflexivo. Boletim Campineiro de Geografia, Campinas, v. 5, n. 1, p. 53-71, 2015.

BALON, R., BERESIN, E. V., e GUERRERO, A. Medical-Education-Industrial Complex? Academic Psychiatry, 42: 495-497, 2018.

BROMBERG, M. The Medical-Industrial Complex: our national defense. Journal of Medicine, $\quad$ New England, 309(21): 1314-1315, 24 Nov. 1983. 
CASTILLO, R., e FREDERICO, S. Espaço geográfico, produção e movimento: uma reflexão sobre o conceito de circuito espacial produtivo. Sociedade \& Natureza, Uberlândia, 22 (3): 461-474, Dez., 2010

CONTEL, F. B. Território e finanças. Técnicas, normas e topologias bancárias no Brasil. 1. ed. São Paulo: Annablume, v. 1.316p., 2011.

CORDEIRO, H. A indústria da saúde no Brasil. Rio de Janeiro: Graal, 1980.

DELPHARM http://www.delpharm.com/fr/qualite-hse/accreditations/

DEZALAY, Y. Marchands de droit. Paris: Fayard, 1992.

DUPUY, J. P., and Karsenty, S. L'invasion pharmaceutique. Paris: Éditions du Seuil, 1974.

ERBER, FS Desenvolvimento industrial e tecnológico na década de 90 - uma nova política para um novo padrão de desenvolvimento. Ensaios FEE 13(1):9-42, 1992.

ERNST \& YOUNG. Consolidation of the CDMO industry: opportunities for current players and new entrants. Report (16p.) September, 2017

FARIA, J. E. O Direito na economia globalizada. São Paulo: Malheiros, 1999.

FRANCE BIOTECH. 2017. Panorama France health tech 2017. Rapport, 15e edition.

FRANCE, Comité économique des produits de santé - CEPS Rapport d'activite 2016. Rapport, 2017.

FRANCE. Les pôles de compétitivité: moteur de croissance et d'emploi. http://competitivite.gouv.fr

FRANCE. Ministere de l'Economie, des Finances et de l'Industrie. Journal officiel de la République Française, 2007.

FRANCE. La place des biotechnologies en France et en Europe. Rapport. Assemblée Nationale, 2005.

FREEMAN, R., e MORAN, M. A. saude na Europa. In: Negri B, Viana ALA, (Org.). O SUS em dez anos de desafio. São Paulo: Sobravime / Cealag; p. 45-64, 2002.

GADELHA, C. A. G. Development, health-industrial complex and industrial policy. Revista de Saúde Pública, 40 (spe), 11-23, 2006. https://dx.doi.org/10.1590/S0034-89102006000400003

GADELHA, C. A. G. O complexo industrial da saúde e a necessidade de um enfoque dinâmico na economia da saúde. Ciência e Saúde Coletiva; 8:521-35, 2003.

HARVEY, D. Spaces or capital. Towards a critical geography. Edinburgh University Press, 2001.

LEEM. Les Entreprises du medicament: bilan economique du secteur du medicament 2017. Rapport, édition 2017a.

LEEM. Enjeux et perspectives des producteurs pour tiers de principes actifs et de médicaments. Rapport, Mars, 2017b.

LEEM. Biomédicaments en France état des lieux 2014. Rapport, Septembre, 2014.

LEEM. and Roland Berger. Repères sur la production pharmaceutique. Rapport, 2018.

EFS. Entreprise Français du Sang. Rapport d'activité 2016. [French Blood Company. Activity Report 2016]

MENDONCA, A. L. O. e CAMARGO Jr., K. R. Complexo médico-industrial/financeiro: os lados epistemológico e axiológico da balança. Physis, Rio de Janeiro, v. 22, n. 1, p. 215-238, 2012. http://dx.doi.org/10.1590/S0103-73312012000100012.

MILLER, J. Contract Manufacturing Through the Years. Pharmaceutical Technology magazine (article is reprinted from the July 2017). Pharmaceutical Technology Volume 41, Issue 7, p 76-78, 2017. $\mathrm{http} / /$ www.pharmsource.com/contract-manufacturing-through-the-years/ 
$\begin{array}{llll}\text { ORBIS } & \text { PLATAFORM. } & \text { Bureau } & \text { Dijk }\end{array}$

https://www.bvdinfo.com/en-us/our-products/data/international/orbis

PERRAT, J. Division spatiale du travail et nouvelles organisations productives: des territoires "segments" aux territoires "modules"?. Innovations, n. 24 (2), 91-114, 2006. https://doi.org/10.3917/inno.024.0091

QUINTILES/IMS. Outlook for Global Medicines through 2021. Report by the QUINTILES/IMS Institute, 2017.

RELMAN, A. The New Medical-Industrial Complex, New England Journal of Medicine (303) 17, 23 October, 1980.

ROLAND BERGER. Comment relancer la production pharmaceutique en France? Rapport, octobre, 2014.

SALOMON, J. C. The medico-industrial complex - Some seldom asked questions. November, Cancer Journal 11(6):268-271, 1998.

SANOFI. Document de référence 2016.

SANTOS, M. A natureza do espaço: técnica e tempo, razão e emoção. São Paulo: HUCITEC, 1996.

SANTOS. Da política dos Estados à política das empresas. Cadernos da Escola do Legislativo. São Paulo, julho/1997.

SANTOS. Metamorfoses do espaço habitado. São Paulo, Nobel, 1988.

SANTOS e SILVEIRA, M. L. O Brasil: território e sociedade no início do século XXI. Rio de Janeiro/São Paulo: Record, 2001.

SCOTT, A. J., and STORPER, M. High technology industry regional development: a theoretical critique and reconstruction. International Social Science Journal 112, 215-232, 1987.

SCOTT, A. J. Creative cities: conceptual issues and policy questions. Journal of Urban Affairs, 28(1), 1-17, 2006. Retrieved from https://escholarship.org/uc/item/77m9g2g6.

STARR, P. The New Entrepreneurialism in Health Care, The New York Academy of Medicine (61) 1, January/February, 1985.

STARR, P. The Social Transformation of American Medicine. New York: Basic Books, 1983.

U.S. CENSUS BUREAU: Economic Indicators Division USA Trade Online. Source: U.S. Import and $\begin{array}{llll}\text { Export } \quad \text { Merchandise trade } & \text { 1982-4513. }\end{array}$ https://www.census.gov/foreign-trade/index.html

VIANA, A. L., SILVA, H. P., and ELIAS, P. E. Economia política da saúde: Introduzindo o debate. Divulgação em Saúde para Debate, Rio de Janeiro, n. 37, p. 7-20, January/ 2007.

VIANNA, C. M. M. Estruturas do Sistema de Saúde: do Complexo Médico-industrial ao Médico-financeiro. PHYSIS: Rev. Saúde Coletiva, Rio de Janeiro, 12(2):375-390, 2002 